\title{
MITOS NYAI RORO KIDUL DALAM NOVEL SANG NYAI
}

\author{
Suci Andari, Safrina Noorman, Teddi Muhtadin \\ Program Pascasarjana Sastra Kontemporer \\ Fakultas Ilmu Budaya Universitas Padjadjaran
}

\begin{abstract}
This writing titled "Mitos Nyai Roro Kidul dalam Novel Sang Nyai". The data is a mythical story of Nyai Roro Kidul on the Sang Nyai novel as a reference text. The theory used structural analysis refers to the actansial Greimas. Based on the structure of the search results found work in seven events in actant scheme that drives the plot of the novel. In this study indicates the utilization of Nyai Roro Kidul myth on the level of plot, character, and background. From the analysis of the structure of meaning found in the form of myths utilization objectification, commodification and demystified
\end{abstract}

Keywords: Actan, Utilization of Myth, meaning

\section{PENDAHULUAN}

"Ratu Kidul" merupakan sosok penguasa Pantai Selatan yang dikenal dengan sebutan Kanjeng Ratu Kidul atau Nyai Roro Kidul. Ia merupakan dewi penjaga Laut Selatan dan penguasa Laut Selatan. Cerita lisan Nyai Roro Kidul sampai saat ini masih sering diperbincangkan, baik oleh yang mempercayai keberadaannya sampai yang tidak mempercayainya.

Di kalangan masyarakat Jawa, Nyai Roro Kidul merupakan sebuah mitos yang terkenal, dan masih terasa hingga kini dalam kehidupan masyarakat Jawa. Mitos ini merupakan sebuah tradisi yang masih bertahan.Ceritanya sampai sekarang tetap terjaga di Keraton Yogyakarta karena mempunyai peran dan pengaruh yang sangat besar dalam sejarah berdirinya kerajaan Mataram sebagai simbol kekuasaan dalam legitimasi politik Jawa. Pada masyarakat yang tinggal di pesisir
Pantai Selatan, seperti halnya daerah pantai Parangkusumo setiap tahunnya selalu diadakan upacara "Labuhan" yang banyak didatangi para peziarah yang ingin mendapatkan berkah dari Nyai Roro Kidul. Lain halnya pada masyarakat Sunda Jawa Barat, cerita Nyai Roro Kidul tidak memiliki pengaruh terhadap tata kehidupan masyarakat pada umumnya, juga tidak ditempatkan sebagai unsur pembentuk negara yang memiliki kepentingan terhadap tatanan politik pemerintahan. Namun, bagi sebagian masyarakat Jawa Barat yang berada di daerah Pangandaran dan Pelabuhan Ratu, cerita ini besar sekali pengaruhnya terhadap pola kehidupan bermasyarakat.Mereka sangat meyakini keberadaan Nyai Roro Kidul sebagai penguasa Laut Selatan. Ini terbukti dari diadakannya upacara ritual taunan yang dikenal dengan sebutan hajat laut di daerah Pangandaran hal ini dilakukan untuk 
menghormati keberadaan penguasa Pantai Selatan.

Dalam masyarakat tradisional, mitos memainkan peran sebagai pedoman tingkah laku masyarakat karena diyakini mendapat campur tangan leluhur (Daeng,2000). Berbagai kegiatan yang bekaitan dengan mitos tertentu masih dilestarikan dan diselenggarakan oleh masyarakat. Demikian pula, dengan mitos Nyai Roro Kidul yang masih dipercaya secara turun temurun oleh masyarakat Jawa. Dalam hal ini, mitos dapat memberikan arah kepada manusia dalam melakukan suatu kegiatan. Dengan demikian, dapat dikatakan bahwa mitos Nyai Roro Kidul merupakan milik masyarakat Jawa telah diwarisi secara turun-temurun dari nenek moyangnya. Mitos ini mendorong masyarakat untuk melakukan suatu kegiatan yang berkaitan dengan mitos tersebut. Terbukti setiap tahunnya masyarakat kolektif pemilik cerita di daerah pesisir Pantai Selatan melaksanakan upacara labuhan Jaladri dengan tujuan untuk keseimbangan hidup.

Tujuan untuk mencapai keseimbangan hidup bagi masyarakat kolektif pemilik cerita yang mempercayai adanya kekuatan dari sosok Nyai Roro Kidul ini, tercermin dalam cerita novel Sang Nyai, masyarakat di sekitar Cepuri Parangkusumo Yogyakarta setiap tahunnya selalu melakukan upacara ritual jaladri tersebut. Cerita Nyai Roro Kidul bermula dari versi lisan dan mempunyai kedudukan yang khusus dalam kesusastraan Jawa. Mitos Nyai Roro Kidul mempunyai banyak kemungkinan terjadinya transformasi bentuk dari bentuk lisan ke bentuk tertulisnya yaitu ke bentuk dongeng, novel, dan film bahkan dalam bentuk tulisan nonfiksi. Seperti halnya pada cerita Nyai Roro Kidul dalam versi Babad Tanah Jawi yang sudah dialih-aksarakan, Nyai Roro Kidul ditempatkan sebagai sosok yang penting dalam cerita, dan ditempatkan sebagai sosok pembentuk negara yang berhubungan dengan raja Mataram yaitu Senapati.

Mitos Nyai Roro Kidul ini tidak hanya ditulis dalam berbagai bentuk cerita dongeng, sejarah, maupun film tetapi juga dalam bentuk cerita rekaan yang dijadikan objek dalam penelitian ini yaitu novel karya Budi Sardjono yang berjudul Sang Nyai (2011). Novel ini merupakan cerita rekaan pertama yang menulis kisah Nyai Roro Kidul dengan latar belakang masa kini.

Di dalam novel Sang Nyai ceritanya berkaitan erat dengan sosok Nyai Roro Kidul. Masalah yang diteliti pada penelitian ini adalah pemanfaatan mitos Nyai Roro Kidul yang terdapat dalam novel Sang Nyai, dan sejauh mana pengarang memanfaatkan mitos Nyai Roro Kidul yang berkembang dimasyarakat sebagai sebuah kekayaan tradisi lisan yang sudah mengalami perubahan ke dalam berbagai bentuk transformasi. Salah satu bentuk transformasinya adalah novel Sang Nyai. Sebagaimana pendapat Ong (1982), sastra tertulis mempunyai hubungan timbal balik dengan sastra lisan. Artinya, sastra lisan bisa digunakan sebagai dasar dari sastra tulisan atau sebaliknya sastra tulisan dapat digunakan sebagai dasar pijakan dari sastra lisan. Kesimpulannnya, setiap karya baik 
lisan ataupun tulisan dapat bertukar genre.

\section{Metode Penelitian Dan Kajian Teori}

Penelitian dilakukan dengan langkah awal mencari objek penelitian yaitu dari mitos Nyai Roro Kidul dengan cara menentukan teks yaitu novel Sang Nyai. Setelah ditentukan maka teks dibaca secara close reading dengan membaca secara berulangulang.

Setelah dilakukan close reading, untuk mengetahui pemanfaatan dan makna mitos Nyai Roro Kidul dalam novel, teks dianalisis secara struktur melalui skema aktansial dengan melihat perubahan tokoh dalam Sang Nyai, alur dalam Sang Nyai, latar dalam Sang Nyai,yang menghasilkan pemanfaatan produksi teks pada tataran alur, tokoh dan latar. Setelah analisis struktur dilakukan terlihat bagaimana mitos Nyai Roro Kidul ini dimanfaatkan pengarang serta makna mitos Nyai Roro kidul yang terkandung dalam novel Sang Nyai.

Untuk mempertegas analisis struktur digunakan analisis dengan menggunakan metode Greimas mengenai skema aktan dan skema fungsional, yang berkaitan dengan alur cerita dalam novel Sang Nyai. Greimas menyusun kembali skema propp sekaligus pada fungsi dan kerangkanya.

\section{PEMBAHASAN}

Dalam mendapatkan informasi mengenai Nyai Roro Kidul Samhudi sebagai pelaku utama digerakkan oleh beberapa peristiwa yang dilaluinya, urutan peristiwa pertama adalah pencarian informasi mengenai Nyai Roro Kidul, kedua peristiwa Mas Darpo dengan seorang Kuncen Cepuri Parangkusumo, peristiwa ketiga dengan seorang perempuan cantik bernama Kesi, peristiwa keempat dengan Kang Petruk seorang penjaga Merapi, peristiwa kelima dengan Nyai Mundingsari seorang janda cantik kaya raya, peristiwa keenam pertemuannya dengan Nyai Maryatun seorang pembatik Sido mukti.

Berikut temuan skema aktan utama yang menjadi dasar dari keenam skema aktan berikutnya yang membawa Samhudi pada tujuan akhir yaitu tahap kegemilangan mengenai keyakinannnya terhadap keberadaan Nyai Roro Kidul. 


\section{Mitos Dalam Novel}

Skema aktan utama di atas menunjukkan adanya mitos Nyai Roro Kidul dalam novel Sang Nyai. Seperti halnya di antara subjek dan objek ada sebuah usaha, yaitu usaha Samhudi
Jawa dan kepercayaan masyarakat terhadap Keraton membantu Samhudi untuk menemukan Nyai Roro Kidul. Untuk mendapatkan keinginannya Samhudi menemukan tantangan, penentang dalam hal ini yaitu ketika

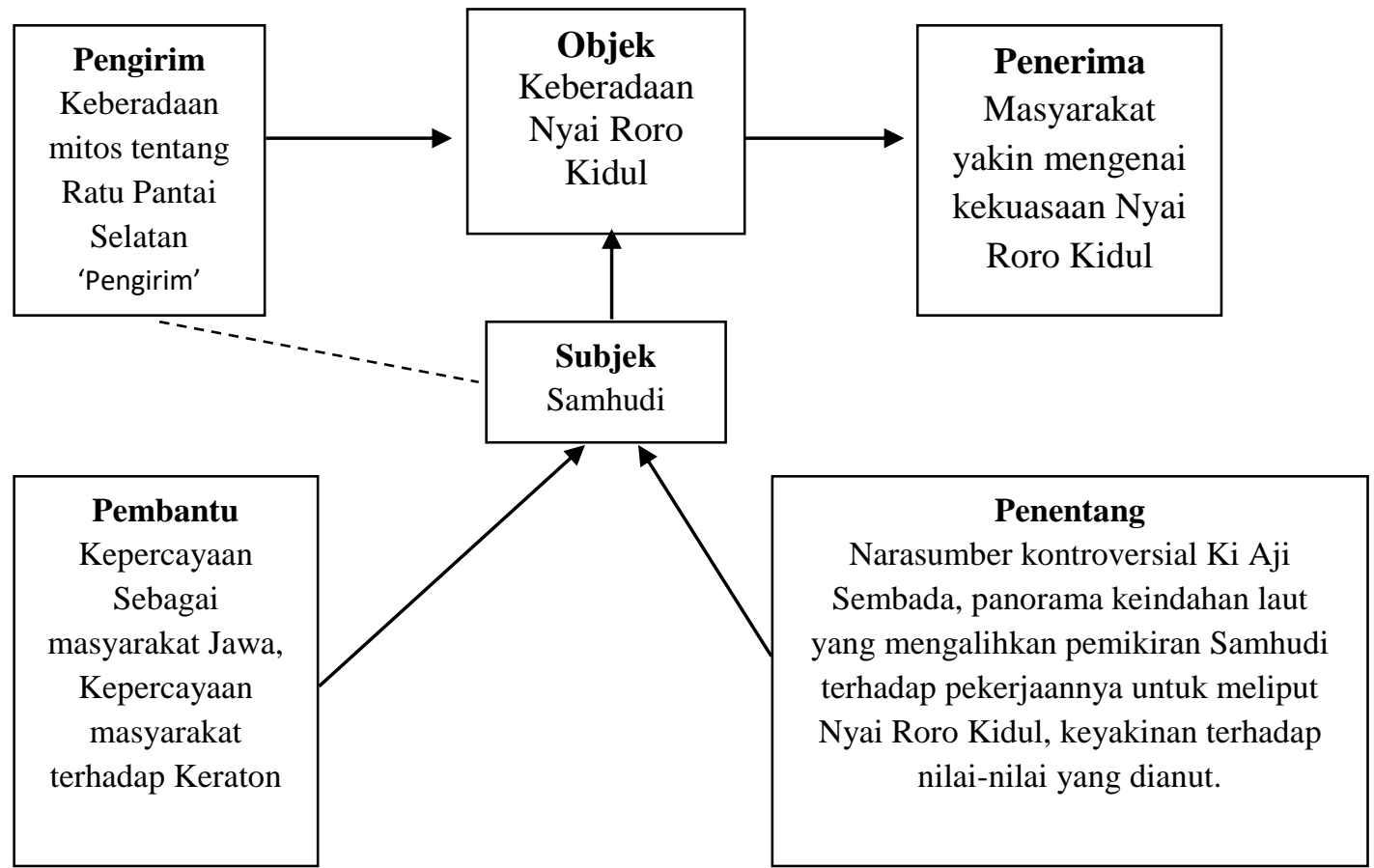

untuk menemukan keberadaan Nyai Roro Kidul, antara pengirim dan subjek terdapat perjanjian, perjanjian tersebut adalah keberadaan mitos tentang Ratu Pantai Selatan yang selama ini berkembang di masyarakat membuat rasa ingin tahu Samhudi terhadap kebenaran mitos Nyai Roro Kidul yang sebenernya cukup besar hal tersebut mendorong Samhudi untuk mencari keberadaan Nyai Roro Kidul. Di antara pengirim dan penerima adanya komunikasi, yaitu komunikasi antara pemahaman mitos Nyai Roro Kidul yang ada di tengah masyarakat yang meyakini kekuasaan Nyai Roro Kidul. Berikutnya antara penolong dan subjek terdapat bantuan, yaitu kepercayaan sebagai masyarakat
Samhudi bertemu dengan salah satu nara sumber yang tidak percaya terhadap sosok Nyai Roro Kidul, dan nilai-nilai yang dianut oleh Samhudi sendiri. Berikutnya uraian mengenai beberapa peristiwa yang menggerakkan cerita dari situasi awal ke situasi akhir.

Dalam Skema Fungsional, menggambarkan Situasi Awal, dimana Samhudi diperintahkan oleh $\mathrm{Pa}$ Yos atasannya untuk menulis feature tentang Nyai Roro Kidul. Tedapat dalam teks "Tetapi ternyata, aku memperoleh ... (37). Situasi awal ini terbagi menjadi beberapa Tahap Uji Kecakapan, utama, dan akhir. Tahap Uji Kecalapan meliputi, Pertama, Samhudi berangkat ke Yogyakarta 
tepatnya ke daerah pantai Cepuri Parangkusumo untuk menemui Mas Darpo dan diberikan kepadanya untuk meliput Nyai Roro Kidul. Ketiga ketika Mas Darpo masuk ke dalam rumahnya, tiba-tiba ada seorang gadis cantik menghampiri Samhudi dan menggodanya. Keempat kedekatan Samhudi dengan perempuan misterius yang sangat cantik itu membawa mereka pada hubungan yang lebih intim.Kesi mengajak Samhudi pergi ke sebuah gubuk di tepi pantai, selain bercengkrama mereka bisa leluasa melakukan hubungan layaknya suami istri.Kesi berjanji untuk memberikan informasi tentang Nyai Roro Kidul. Kelima setelah kejadian di gubuk antara Samhudi dan Kesi, Samhudi diajak oleh Kesi untuk pergi menemui Kang Petruk seorang penjaga Merapi.Samhudi dijemput oleh Supir Andong bernama Kang Jiman untuk sampai ke kediaman Kang Petruk. Ketika sudah sampai di kediaman Kang Petruk timbul penentang, yaitu keyakinan dalam hati Samhudi sebagai manusia yang memiliki keyakinan terhadap nilai-nilai yang dianut. Keenam, setelah Samhudi mengunjungi rumah Kang Petruk, Samhudi lalu pergi ke rumah narasumber yang lain untuk mencari informasi yang lebih akurat tentang Nyai Roro Kidul. hingga suatu saat Samhudi diantar Sugeng seorang tukang ojek ke rumah Nyai Mundingsari, seorang janda cantik yang kaya raya yang dikenal memiliki kedekatan khusus dengan Nyai Roro Kidul karena kepemilikan tujuh lukisan Nyai Roro Kidul dan bendabenda pusaka lainnya. Ketika Samhudi dihadapkan situasi tersebut, timbul penentang yaitu Samhudi tidak percaya dengan adanya cerita mistis yang terjadi dengan ketujuh lukisan dalam rumah Nyai Mundingsari yang datang begitu saja tanpa dibawa oleh siapa pun.

Tahap yang kedua adalah Tahap Utama. Pada tahapan ini banyak peristiwa yang sudah dialami oleh Samhudi dalam mencapai keinginannya untuk mendapatkan informasi tentang Nyai Roro Kidul.pada awalnya Samhudi tidak merasa yakin dengan apa yang ditemuinya dan keberadaan sosok Nyai Roro Kidul. Hingga suatu saat keyakinan Samhudi muncul ketika bertemu dengan Nyai Maryatun seorang pembatik yang memiliki uang logam emas dengan gambar perempuan cantik.

Ketiga, Tahap Kegemilangan. Setelah bertemu dengan Nyai Maryatun dan melalui berbagai peristiwa, Samhudi pulang kembali ke kota asalnya Jakarta. Pengalamannya di Jogja merupakan pengalaman luar biasa baginya bahkan menimbulkan banyak teka-teki.Sesampainya Samhudi di Jakarta dia mendapatkan kado berwarna abu.Hadiah tersebut menjawab semua teka-teki misterius mengenai mitos Nyai Roro Kidul.Samhudi dinyatakan berhasil dalam mencapai keinginannya, karena dirinya bisa bertemu langsung dengan Nyai Roro Kidul dan meyakini keberadaannya.

Terakhir Tahap Akhir, Setelah Samhudi menerima kado dan membukanya, dirinya meyakini bahwa perempuan cantik yang ia temui adalah Nyai Roro Kidul dan semua peristiwa yang dialaminya saling berkaitan. 
Samhudi dinyatakan berhasil karena keinginannya untuk mencari informasi tentang Nyai Roro Kidul hasilnya diluar dugaan, dan sangat memuaskan. Berdasarkan penelusuran skema aktan diperoleh pola yang ada dalam cerita. Dalam novel Sang Nyai terdapat skema aktan dasar yang memuat mitos Nyai Roro Kidul dan ada enam skema aktan yang menggerakkan cerita yaitu, pencarian informasi Nyai Roro Kidul, peristiwa Mas Darpo Kuncen Parangkusumo, peristiwa Kesi seorang perempuan cantik, peristiwa dengan Kang Petruk seorang penjaga Merapi, peristiwa dengan Nyai Mundingsari, peristiwa dengan Nyai Maryatun.

\section{Pandangan Hidup Masyarakat Kolektif (Jawa)}

Beberapa hal yang dijadikan pandangan hidup masyarakat kolektif dalam novel Sang Nyai berdasarkan skema aktan utama mitos dalam novel yaitu kepercayaan masyarakat Jawa dan masyarakat Keraton. Raja merupakan orang yang memusatkan suatu takaran kekuatan kosmis yang besar dalam dirinya sendiri, sebagai orang yang sakti sesakti-saktinya. Raja bisa dianggap sebagai pintu air yang menampung seluruh air sungai dan bagi tanah yang lebih rendah merupakan satu-satunya sumber air dan kesuburan. Kekuasaan raja merupakan anugerah yang diberikan oleh yang maha kuasa. Dan masyarakat Jawa percaya raja memiliki potensi untuk memberikan anugerah terhadap rakyatnya.

Keraton sebagai pusat kerajaan, bagi masyarakat Jawa keraton bukan hanya suatu pusat politik dan budaya, melainkan juga merupakan pusat keramat kerajaan.Keraton adalah tempat raja bersemayam, dan raja merupakan sumber kekuatan-kekuatan yang mengalir ke daerah membawa ketentraman, keadilan, dan kesuburan. Keraton Jogjakarta merupakan simbolisasi dari sang pemimpin yang bergelar Ngarso-Dalem, yang mengandung arti pemimpin yang senantiasa di depan sebagai teladan. Di dalam novel Sang Nyai pun, keagungan keraton itu tersirat dalam praktik lingkungan yang dilakukan Mas Darpo seorang kuncen Parangkusumo yang memaknai segala bentuk berkah dan kenikmatan yang dirinya dapati merupakan bentuk kemurahan hati Ngarsa Dalem, yang memberikan wahyu untuk selalu melayani para peziarah.

Gunung Merapi dipercaya oleh masyarakat Jawa sebagai keraton makhluk halus tempat tinggal para roh leluhur.Merapi juga digunakan penduduk setempat sebagai kerangka landasan untuk beradaptasi dan berinteraksi serta mendayagunakan sumber daya Merapi.Kepercayaan ini diyakini pula oleh Keraton Jogjakarta yang diwujudkan dalam bentuk upacara labuhan Gunung Merapi (Minsarwati, 2002:36).Upacara labuhan adalah salah satu bentuk upacara religious yang mempunyai makna kosmologis karena di sini terjalin hubungan yang harmonis antara kestuan makrokosmos dan mikrokosmos yaitu, hubungan antara Gunung Merapi-Keraton JogjakartaLaut Selatan.Sebagian masyarakat Jawa percaya bahwa terjadinya letusan Gunung Merapi dikarenakan sebagai pertanda perkawinan antara dewa laki- 
laki yaitu Kyai Sapu Jagad dan perempuannya Nyai Roro Kidul. Dalam novel Sang Nyai terdapattragedi peristiwa letusan Gunung Merapi, melibatkan Samhudi yang diberikan kepercayaan oleh Kang Petruk untuk memberitahukan kepada masyarakat setempat agar semua penduduk di daerah lereng Merapi berhati-hati dan waspada.

Laut Selatan mengandung kekayaan alam yang tidak terhingga.Nyai Roro Kidul yang diyakini sebagai penguasa Laut Selatan memiliki kuasa atas kebaikan dan keburukan yang dirasakan oleh penduduk setempat. Jika kehidupan masyarakat sentosa dan tentram, itu dikarenakan sang penguasa bermurah hati. Seballiknya, jika kehidupan masyarakat sekitar mengalami musibah atau bencana, maka dpahami bahwa sang ratu sedang murka. Eksistensi Laut Selatan sebagai salah satu wujud sikap kosmologis masrakat Jawa, sampai saat ini masih memiliki pengaruh yang besar bagi kehidpan warga di sekitarnya.Hal ini tercermin dalam cerita novel Sang Nyai.Pengaruhnya sangat besar terhadap kehidupan sehari-hari masyarakat kolektif pemilik cerita.

Berdasarkan uraian di atas, tiga makna simbol Gunung Merapi, Keraton Jogjakarta, dan Laut Selatan dapat disimpulkan bahwa kepercayaan yang diyakini oleh masyarakat kolektif, mempengaruhi cara pandang sebuah masyarakat dan terbawa dalam sikap sehari-harinya. Tiga garis imajiner yang menghubungkan tiga kekuatan simbol Merapi, Keraton, dan Laut Selatan terdapat dalam cerita novel Sang Nyai.Mengenai Mitos Nyai
Roro Kidul yang berkembang dimasyarakat tidak bisa terlepas dari makna simbol yang ada. Pada Sang Nyai, penulis mendayagunakan tiga kekuatan simbol tersebut dalam cerita. Terdapat beberapa unsur yang di manfaatkan oleh pengarang untuk mengukuhkan kebenaran mitos Nyai Roro Kidul.

Pemanfaatan pada tokoh tampak pada pelukisan tokoh, jumlah tokoh, dan kualitas tokoh. Pelukisan tokoh dalam cerita novel Sang Nyai ketika ditransformasi, adalah teknik ekspositori. Teknik ini juga disebut sebagai teknik analitis, pelukisan tokoh cerita dilakukan dengan memberikan deskripsi, uraian, atau penjelasan secara langsung.Tokoh yang dihadirkan oleh pengarang tidak berbelit-belit, melainkan begitu saja dan langsung disertai deskripsi kediriannnya.

Dalam novel penamaan tokoh tidak hanya berasal dari Jawa saja. Tetapi, ada pula dalam bahasa Indonesia dan sebutan untuk kaka lakilaki. Salah satunya tokoh Kang Petruk, "Kang" artinya panggilan untuk kakak laki-laki pada orang Sunda dan di Jawa sendiri ada sebutan "Kang Mas". Petruk sendiri adalah tokoh punakawan dalam pewayangan Jawa, di tanah pasundan Petruk lebih dikenal dengan nama Dawala atau udel. nama tokoh wayang yang khas dengan hidung panjangnya yang juga tokoh pelawak ini digambarkan secara ekpositori, tokoh ini secara langsung di deskripsikan dengan tidak berbelitbelit. (Sang Nyai, 2011:80)

Identitas si tokoh termasuk jajaran abdi dalem Keraton Yogyakarta yang berpangkat lurah. 
Diantara para abdi dalem Darpo dipanggil dengan nama mas lurah. Panggilan tersebut, merupakan panggilan kehormatan.Meski gajinya tidak mencukupi untuk kebutuhan sehari-hari namun dirinya diberi tugas oleh Ngarsa Dalem untuk melayani peziarah.

Jumlah Tokoh dalam novel terdapat tokoh Samhudi, Kesi, Nyai Mundingsari atau Bu Mul, Mas Darpo (kuncen), Kang Petruk, Kang Jiman (kusir), Pa Nung (peziarah), Ki Aji Sembada (narasumber kontroversial), Sugeng (tukang ojek), Nyai Maryatun (pengrajin batik), Damar Kusumo (pangeran) dan Sasongko (staff hotel). Nama tokoh dalam cerita lisan yang ditulis di dalam babad merupakan nama dalam bahasa Jawa, "Senapati" atau dikenal dengan sebutan Panembahan Senopati merupakan pendiri Dinasti Mataram pertama yang bertahkta pada tahun 1575-1601. Kata "Nyai" sendiri merupakan sebutan umum masyarakat Sunda dan Jawa khususnya bagi wanita dewasa.Pada masa kolonial seorang Nyai berada dalam posisi yang tinggi secara ekonomis tapi rendah secara moral. Sedangkan "Ratu" adalah lambang perempuan atau wanita, yang memiliki daya tarik luar biasa. Adapun yang dimaksud dengan kata Kidul "Selatan" adalah lambang kerakyatan dan lambang duniawi atau hal-hal yang bersifat lahiriah.Dengan demikian Ratu Kidul adalah segala sesuatu yang bersifat duniawi atau yang lahiriah, yang mempunyai daya tarik luar biasa.Bahkan dapat menggoda serta meruntuhkan iman seseorang. Sedangkan nama yang berasal dari Indonesia adalah Samhudi dan Kesi.

Kualitas tokoh adalah jenis peran pada setiap tokoh yang mempengaruhi kedudukan serta kualitas si tokoh tersebut dalam cerita. Kedudukan Nyai Roro Kidul dalam mitos jelas digambarkan sebagai Ratu penguasa dan Senapati merupakan cikal bakal Raja Mataram yang diberikan wangsit untuk berguru kepada Nyai Roro Kidul.Hal ini menandakan adanya kekuasaan penuh pada tokoh mitos Nyai Roro Kidul dalam cerita Babad.

Sang Nyai Dari dua belas tokoh yang ada, Sembilan masuk dalam tokoh sederhana. Dalam bentuknya yang asli merupakan tokoh yang hanya memiliki satu kualitas pribadi tertentu, sebagai seorang tokoh manusia, ia tak diungkap sisi kehidupannnya dengan lebih mendalam. Intensitas kemunculannya pun tidak berulang. Terdapat satu tokoh bulat yang memiliki karakter ganda yaitu : (1) Kesi seorang perempuan cantik yang misterius yang memiliki perubahan rupa dan nama .yaitu berubah menjadi, $\mathrm{Bu}$ Mul atau Nyai Mundingsari, dan Nyai Maryatun.

Sosok Nyai Roro Kidul itu menjelma menjadi sosok perempuan cantik yang misterius bernama Kesi, berbeda dengan sosok Nyai Roro Kidul di dalam novel tidak disebutkan secara eksplisit identitasnya, hanya saja sosoknya menjelma menjadi beberapa tokoh perempuan yang memiliki sifat dan watak yang berbeda. Tokoh ini menampilkan watak dan tingkah laku bermacammacam, bahkan bertentangan dan sulit diduga, oleh karena itu perwatakannya 
pun sulit dideskripsikan secara tepat, hanya saja tokoh Kesi yang berperan ganda menjadi sosok Nyai Mundingsari dan $\mathrm{Bu}$ mul memiliki berbagai macam sikap dan tindakan dan bahkan ia sering memberikan kejutan.

Kualitas tokoh ini tampak juga pada tokoh Nyai Roro Kidul dalam mitos Babad Tanah Jawi ketika bertemu dan menghampiri Senapati, Nyai Rara Kidul merayu dan membawa Senapati ke keratonnya di dasar laut (Babad Tanah Jawi,1980:105). Dimana Nyai Roro Kidul memiliki relasi dengan orang yang berkuasa di tanah Jawa serta memiliki daya pikat yang kuat sehingga dapat meluluhkan hati Raja Mataram. Sang Nyai Nyai Roro Kidul tidak diceritakan secara nyata karena sosoknya hidup sebagai mitos yang dipercaya oleh masyarakat kolektif pemilik cerita. Oleh karena itu aura Nyai Roro Kidul dimiliki oleh Kesi perempuan cantik yang misterius dan memiliki kekuatan daya pikat yang besar untuk membuat laki-laki jatuh hati padanya (Sang Nyai, 2011:23).

Adanya pemanfaatan yang menggambarkan latar ketika mitos Nyai Roro Kidul bertransformasi ke dalam novel tidak hanya perubahan latar tempat dan waktu, namun latar sosial dan latar spiritual juga di munculkan.

Latar sosial dan spiritual disini terkait dengan kebiasaan masyarakat, adat istiadat, kepercayaan, tradisi, pandangan hidup, cara berpikir dan bersikap yang dianut selama ini. Hal ini terlihat dari perbincangan Samhudi dengan Mas Darpo yang seorang kuncen Cepuri Parangkusumo, Mas
Darpo digambarkan sebagai seseorang yang menganut kepercayaan penuh terhadap tradisi melalui pandangan hidupnya terkait dengan gejala spiritual yang ada. (Sang Nyai, 2011:9). Tokoh Mas Darpo ini dapat diketahui bahwa dirinya merupakan salah satu masyarakat kolektif pemilik cerita yang mempercayai segala bentuk kuasa alam, maka dirinya selalu bersikap hati-hati dalam menjaga keseimbangan hidupnya. Bahasa daerah yang digunakan pada kutipan kedua "ngegirisi" menunjukkan local colour latar tempat dimana perbincangan itu berlangsung, yaitu di daerah Jawa tepatnya di sekitar pantai Cepuri Parangkusumo (Sang Nyai, 2011:10). Pandangan hidup tersebut jika ditinjau dari filsafat orang Jawa ada kesamaan seperti yang diungkapkan oleh Ki Tirtahamidjaja dalam bukunya yang berjudul Mitos Ratu Kidul dalam perspektif Budaya, mengungkapkan bahwa konsep Ratu Kidul merupakan konsep hidup yang insani atau duniawi. Konsep dapat bermakna vertikal yang artinya berhubungan dengan manusia dan tuhannya.Pada kutipan diatas serupa dengan makna yang diungkapkan pada buku tinjauan filsafat Jawa yang artinya keseimbangan hidup antara manusia dan manusia dan manusia dengan Tuhannnya. Mas Darpo sebagai seorang masyarakat kolektif yang mempercayai keberadaan Nyai Roro Kidul merasa apa yang sudah diberikan kepadanya merupakan berkah dari Nyai Roro Kidul.

\section{Unsur Mitos Nyai Roro Kidul Novel Sang Nyai}


Pemanfaatan unsure mitos Nyai Roro Kidul dalam novel, terdapat pada beberapa unsur yang meliputi alur, tokoh dan latar. Alur dalam novel menjelaskan kehidupan seorang pria yang bernama Samhudi dalam pencariannnya menemukan sosok Nyai Roro Kidul melalui berbagai nara sumber untuk bahan penulisan artikelnya. Samhudi dalam arti sebenarnya tidak pernah bertatap muka langsung dengan sosok Nyai Roro Kidul, namun sosok itu menjelma ke beberapa perempuan cantik yang ia temui dalam berbagai kesempatan. Sebut saja Kesi, Nyai Mundingsari atau $\mathrm{Bu}$ Mul, dan terakhir Nyai Maryatun seorang pengusaha rumahan bakti sidomukti.

Dalam mitos Nyai Roro Kidul direpresentasikan sebagai seorang Ratu yang memiliki tahkta tertinggi di laut Selatan, memimpin ribuan prajurit jin dan peri. Sosok penguasa Nyai Roro Kidul dalam mitos memiliki kekuasaan penuh di sepanjang Laut Selatan dan area Keraton Kasunan Jogjakarta. Sang Nyai yang dimaksud adalah sosok-sosok perempuan yang memiliki pesona Nyai Roro Kidul. adalah peran utama Samhudi yang mengalami banyak peristiwa-peristiwa di dalamnya, dari mulai pertemuannnya dengan Mas darpo di pantai Cepuri Parangkusumo, kunjungannnya ke rumah Kang Petruk, pertemuannnya dengan Kesi perempuan misterius, disusul dengan peristiwa meditasi yang ia lakukan di rumah Nyai Mundingsari, lalu pengalaman gaibnya berada di tempattempat yang memang melekat dengan sosok Nyai Roro Kidul yaitu Samudera Beach Hotel, Sanur Beach
Hotel, Panggung Sanggabuwana, wawancaranya dengan budayawan kontroversial Ki Aji Sembada, menjadi saksi hidup meletusnya gunung Merapi, dan terakhir kunjungannnya ke makam Imogiri sekaligus pertemuan singkatnya dengan Nyai Maryatun seorang pembatik parangrusak. Peristiwa-peristiwa yang dialaminya tersebut, seolah ingin menegaskan bahwa mitos Nyai Roro Kidul ini benar-benar ada dan dialami sendiri oleh seorang Samhudi. Sehingga, dengan sengaja nama-nama tempat dan berbagai peristiwa seperti sebuah pengalaman sendiri yang dialami oleh seseorang dan tempat tersebut tidak asing lagi kita dengar karena dekat dengan keberadaan kita sebagai pembaca.

Berbeda dengan cerita dalam mitos Nyai Roro Kidul dideskripsikan sebagai seorang Ratu yang dipertemukan dengan Senapati cikal bakal Raja Mataram.Ratu Kidul sendiri ditempatkan sebagai unsur penting dalam cerita karena memiliki kuasa terhadap Senapati. pola demikian dapat dikatakan inferioritas. Novel ini di dominasi dengan cerita mengenai kecantikan, percintaan sesaat, dan kemolekan tubuh perempuan sehingga peran penting seorang Ratu bergeser menjadi perempuan biasa yang tidak memiliki kepentingan dalam ranah kekuasaan.

Dalam Pemanfaatan Mitos pada Tokoh terdapat pergeseran peran utama protagonis dan tokoh utama dalam Sang Nyai bukan tokoh Nyai itu sendiri. Samhudi merupakan tokoh utama yang banyak diceritakan dan selalu berhubungan dengan tokohtokoh lain, ia sangat menentukan 
perkembangan alur secara keseluruhan. Samhudi pun selalu hadir sebagai pelaku, dan dikenai konflik dan kejadian. Disisi lain kemunculan tokoh-tokoh tambahan dalam keseluruhan cerita lebih sedikit, terkesan tidak dipentingkan, dan kehadirannnya hanya jika ada keterkaitannnya dengan tokoh utama, secara langsung ataupun tak langsung.

Kesi sebagai representasi Sang Nyai yang merujuk pada tokoh Nyai Roro Kidul tidak secara terperinci diuraikan, sosok Kesi muncul tenggelam dalam novel, kedudukannnya adalah sebagai objek dalam cerita.

Ada yang berbeda dalam teknik penokohan dalam novel ini, yaitu hadirnya tokoh-tokoh yang ada dalam dunia nyata (Sang Nyai, 2011:11 dan 24). Hadirnya nama Mbah Maridjan dan Suzana, menunjukkan adanya usaha untuk menempatkan cerita dalam novel ini bukan hanya cerita rekaan tetapi memang cerita ini benar-benar terjadi. Hal ini didukung Peristiwa pertemuannnya dengan pangeran Solo, semakin memperjelas bahwa hal ini dilakukan sebagai usaha untuk meyakinkan kepada pembaca bahwa cerita ini bukanlah cerita rekaan semata, tetapi mitos Nyai Roro Kidul yang ada dalam teks dasarnya adalah cerita sejarah yang harus diyakini oleh pembaca sebagai masyarakat Indonesia, yang masih memegang tradisi dan kebudayaannnya. Tokoh Nyai Roro Kidul sendiri tidak dihidupkan secara eksplisit namun hegemoni kekuasaanya dapat dirasakan dan memiliki pengaruh terhadap tatanan kehidupan bermasyarakat khususnya masyarakat yang tinggal di sekitar Laut Selatan. (Sang Nyai, 2011:237)

Latar waktu yang terdapat dalam mitos Nyai Roro Kidul tidak secara eksplisit disampaikan, bergantung pada penutur yang bercerita.

Latar yang terdapat dalam novel menunjukkan kedudukan tokoh Nyai Roro Kidul yang merupakan penguasa laut Selatan berdasarkan cerita lisan yang berkembang di masyarakat.Dan samhudi berada di beberapa tempat yang dikenal sebagai tempat persinggahan Ratu Pantai Selatan tersebut. (Sang Nyai,2011:149)

Sanur Beach Hotel merupakan tempat yang dipercaya sebagai tempat persinggahan Nyai Roro Kidul, maka di dalam novel Sang Nyai dimunculkan latar cerita yang menunjukkan hegemoni sang Ratu. Seperti halnya peristiwa yang dialami Samhudi saat dirinya tiba-tiba berada di dalam kamar Nyai Roro Kidul di hotel Sanur Beach yang berlokasi di Bali. Saat itu Samhudi seolah-olah berada di dalam kamar itu saat dirinya melakukan meditasi, dan diluar kesadarannya dirinya dapat merasakan aura mistis, samhudi melihat sekeliling kamar tersebut terdapat sandal perempuan, di atas meja terdapat televise hitam putih berukuran 14 inci, samhudi pun melihat di rak bawah, terdapat kulkas kecil satu pintu.

Hegemoni Nyai Roro Kidul digambarkan lagi pada latar tempat di atas, hotel merupakan tempat penginapan modern. Namun mitos Nyai Roro Kidul masuk ke dalamnya, di dalam kamar tersebut terdapat tempat tidur, kasur, dan televisi.Itu 
semua merupakan tanda-tanda yang tampak yang merupakan identitas kekinian.Hegemoni Nyai Roro Kidul tergambarkan dalam beberapa lukisan yang dilihat oleh Samhudi dikamar hotel tersebut. Dengan mahkota kebesaran dan keris yang terselip terlihat bahwa sosok Nyai Roro Kidul seorang pemimpin pasukan yang gagah perkasa.Latar tempat menunjukkan bahwa Nyai Roro Kidul merupakan seorang penguasa.

Mitos Nyai Roro Kidul juga tertuang dalam cerita babad mempunyai kekuatan dan nilai yang tinggi terlihat dari latar tempat penggambaran sang Ratu Kidul yang tinggal di dalam istana dan bertahkta dalam sebuah kerajaan besar di bawah laut. Istana merupakan tempat kediaman seorang Raja atau Ratu yang dihormati dan memiliki kedudukan tertinggi di seluruh negeri.Namun sebaliknya tokoh Nyai Roro Kidul pada teks dasarnya tidak dihidupkan sebagai seorang penguasa Laut Selatan yang sebenarnya melainkan direpresentasi pada tokoh Kesi dan Nyai Mundingsari dan merujuk pada inferioritas.

Pada novel terdapat modifikasi.Cerita yang bermula dari sebuah cerita dongeng mengalami peneransformasian ke dalam bentuk novel.tentu membutuhkan teknik yang lebih luas dan penggarapan yang berbeda dari teks dasar. Istilah modifikasi ini dikembangkan melalui prinsip Riffatere oleh Pradotokusumo dalam penelitiannya terhadap Kakawin Gajah Mada yang dianalisis melalui suntingan naskah telaah struktur, tokoh dan hubungan antarteks. Mitos Nyai
Roro Kidul yang ditransformasi ke dalam novel Sang Nyai.

Modifikasi alur dihubungkan dengan kejadian realitas kehidupan, gempa Jogja terbesar terjadi pada tahun 2006 lalu. Gempa bumi tektonik kuat yang mengguncang Daerah istimewa Yogyakarta dan Jawa Tengah pada tanggal 27 Mei 2006 kurang lebih pukul 05.55 Wib selama 57 detik. Gempa bumi tersebut berkekuatan 5,9 skala richter. Di dalam novel berita mengenai gempa tersebut disebutkan dengan jelas tahunnya, pada sebuah siaran radio. (Sang Nyai, 2011:399). Dalam hal ini konsep plausibilitas ditampilkan dalam Sang Nyai merupakan kesengajaan, yang merupakan peniruan realitas.

Mitos Nyai Roro Kidul yang tedapat dalam novel mengacu pada cerita mitos Nyai Roro Kidul yang dituliskan dalam Babad Tanah Jawi. Sebagai bahan acuan, alurnya sederhana dan bersifat tradisional, pada halaman pertama Rara Kidul sebagai penguasa Laut Selatan merasa terganggu dan terperanjat ketika dirinya mendengar keributan di laut. Setelah keluar dia melihat seseorang yang sakti yang sedang mengheningkan cipta. Rara Kidul segera menghampiri dan menyembah Senapati, dan dirinya berjanji akan mengabulkan keinginan Senapati menjadi Raja Mataram. Sebagai balas jasa Senapati mengikuti jejak Rara Kidul menuju kerajaan dalam laut dengan tujuan untuk memperdalam ilmunya. Selama tiga hari tiga malam Senapati tinggal seperti suami istri dengan Rara kidul dan setiap hari Senapati diberi wejangan mengenai ilmu jika seseorang memerintah orang, 
jin dan peri. Senapati sangat berterimakasih kepada Rara Kidul karena telah diberi ilmu untuk memerintah kerajaan Mataram, maka dirinya pamit untuk pulang.Sampai saat ini kerajaan Mataram berdiri dan dikenal dengan sebutan Keraton Ngayogyakarta Hadiningrat yang di perintah oleh seorang Sultan yang bergelar Sri Sultan Hamengku Buwana.

Pemanfaatan modifikasi pada tataran alur tampak dari adanya skema aktan. Hal ini tampak pada mitos Nyai Roro Kidul ketika ditransformasi ke dalam sebuah novel. Komposisi yang terdapat dalam novel dimulai dari halaman nomor 5 adalah : halaman 548 (kisah Samhudi di Parangkusumo), 49-102 (kisah Samhudi di rumah Kang Petruk), 103-154 (kisah Samhudi dengan tujuh lukisan), 155-194 (kisah Samhudi ketika mendapat telpon dari Kang Petruk), 195-252 (kisah Samhudi di Panggung Sanggabuwana), 253-300 (kisah Samhudi dengan mitos perahu layar di Kali code), 301-350 (kisah Samhudi di kali Opak), 351-398 (kisah Samhudi pada acara Labuhan Jaladri), 399-435 (kisah Samhudi pada peristiwa Merapi). Tampak dalam setiap peristiwa Samhudi menjadi subjek yang dominan dalam cerita.

Meskipun demikian, Penulis melihat adanya pola yang sama yang terdapat dalam novel. Setiap pergantian bab satu dengan bab selanjutnya Samhudi bertemu dengan nara sumber baru dan tempat yang baru, yang berkaitan dengan Nyai Roro Kidul dan sesuai dengan mitos Nyai Roro Kidul yang berkembang di tengah masyarakat Jawa khususnya masyarakat kolektif pemilik cerita.
Cerita Nyai Roro Kidul terlihat terlihat dari struktur narasi sudut pandang tokoh dan peristiwa sebagai suatu cara narator dikisahkan berjarak dengan pembaca dan tergantung pada penutur karena ceritanya termasuk ke dalam cerita tradisional, namun ketika ditulis menjadi sebuah novel mengalami modifikasi terlihat dari dikembangkannnya cerita menjadi beberapa episode. Hal ini dilakukan untuk memenuhi kriteria penulisan dalam novel yang merupakan bentuk tulisan dari karya sastra modern.Harus lebih padat dan panjang.

Pemanfaatan pada tataran modifikasi tokoh yang dilakukan tidak terlepas dari citra masa lalu kebudayaan masyarakat Jawa yang sudah lama mengenal mitos Nyai Roro Kidul sebagai ciri budaya yang linier dengan kebudayaan Keraton hal ini semakin melegitimasi keberadaan mitos ini. Dalam hal ini sistem penamaannya pun di sesuaikan dengan citra masa lalu.Seperti pada tokoh Kiai Sapu Jagad atau yang lebih dikenal dengan sebutan Mbah Petruk, Mbah Petruk ini dikenal sebagai penjaga gunung merapi.

Terdapat banyak simbol dalam tatanan kehidupan masyarakat Jawa, mereka mengenal adanya kedudukan letak mitis geografi kerajaan Mataram, yaitu bagian Utara ditempati oleh Gunung Merapi yang dihuni oleh Kyai Sapu Jagad, di dalam novel disebut Mbah Petruk, bagian Selatan dihuni oleh Kanjeng Ratu Kidul, dan letak Keraton Mataram berada di tengahtengah. Hal itu pula yang menjadi pertimbangan penulis dalam memunculkan sosok Mba Petruk di dalam novel Sang Nyai karena 
berhubungan langsung dengan mitos Nyai Roro Kidul. (Sang Nyai,2011:100). Tokoh Kang Petruk dimunculkan untuk menguatkan mitos Nyai Roro Kidul yang sudah dikenal selama ini.Samhudi merasa ada kejanggalan ketika dirinya berada di rumah Kang Petruk, seolah-olah dirinya hidup di alam gaib pada saat itu. (Sang Nyai, 2011:172)

Tokoh Mas Darpo dimunculkan semakin menguatkan citra masa lalu. Mas Darpo digambarkan (Sang Nyai, 2011:6) lelaki yang memiliki pakaian yang dikenakan seperti layaknya para abdi dalem yang berada di Keraton, yang masih patuh pada pakem-pakem peraturan yang ada di dalamnya. Muncul juga tokoh Sugeng yang dimodifikasi sebagai pemuda daerah namun dalam berpakain sehari-hari Sugeng memiliki konsep kekinian (Sang Nyai, 2011:106). Tokoh Sugeng digambarkan sebagai pemuda masa kini, dengan memakai pakaian kaus hitam dan celana pendek Sugeng leluasa untuk bergerak dan melakukan aktifitasnya, selain itu disesuaikan dengan jaman pada saat novel itu diceritakan. Hal ini dilakukan sebagai usaha untuk menyesuaikan alur certa dengan konsep masa kini, namun dengan tidak menghilangkan citra masa lampau yang berhubungan dengan mitos Nyai Roro Kidul itu sendiri. hal ini juga dimunculkan pada tokoh Kesi, yang memiliki nama masa kini namun cara berpakainnya masih mengenakan kain (Sang Nyai, 2011:14 dan 90)

Dalam novel Sang Nyai ini menyaran pada sesuatu yang tak logis. (Sang Nyai, 2011:89). Peristiwa yang dialami Samhudi sendiri ketika dirinya dijemput oleh kusir andong misterius bernama Kang Jiman menuju rumah Kang Petruk, Samhudi berada di dunia gaib yang tidak pernah dialaminya sebelumnya. Anakronisme ini merupakan faktor kesengajaan yang sengaja dimunculkan untuk menjembatani imajinasi antara pembaca dengan cerita yang ada di dalam novel tersebut, menurut saya itu juga dilakukan agar unsur spiritual mengenai sosok mitos Nyai Roro Kidul itu sendiri terbangun dan dapat dirasakan oleh pembaca (Sang Nyai, 2011:98). Anakronisme menyaran pada sesuatu yang tidak logis, namun kembali terhadap tujuan penulisan novel tersebut, hal itu juga bisa dikategorikan sebagai faktor kesengajaan, agar suasana gaib yang dimaksudkan oleh pengarang dapat terbangun dan dirasakan oleh pembaca. (Sang Nyai, 2011:99 dan 101) Kedua peristiwa di atas menunjukan ketidaksesuaian yang begitu terlihat jelas, pada kutipan yang pertama, yaitu ketika Kang Petruk yang merupakan tokoh gaib penjaga tungku raksasa, yang juga di asosiasikan sebagai Kyai Sapu Jagad penjaga Merapi. memiliki pengetahuan mengenai telepon genggam, dan tentu saja itu sangat tidak logis. (Sang Nyai, 2011:161)

Transformasi yang paling menonjol juga tampak pada konversi tokoh, terdapat pergeseran peran dari tokoh perempuan yaitu Nyai Roro Kidul dalam cerita mitos ke tokoh lakilaki yaitu Samhudi yang berprofesi sebagai seorang wartawan. Subjek yang berbeda namun memiliki peran yang sama yaitu, kekuasaan. Jika pada 
teks dasar Nyai Roro Kidul mempunyai kuasa terhadap Senapati cikal bakal Raja Mataram.Dalam novel Samhudi memiliki kuasa terhadap beberapa peristiwa penting yang berkaitan dengan sosok Nyai Roro Kidul yang hidup dalam mitos.Hal ini memperkuat dugaan pentingnya peran subjek dalam usaha melanggengkan hegemoni Nyai Roro Kidul.Dalam hal ini Samhudi sebagai tokoh utama, juga menjadi subjek.Terlihat dari penjelasan skema aktan yang menempatkan Samhudi sebagai subjek yang memiliki hasrat untuk mendapatkan objek yaitu semua hal mengenai Nyai Roro Kidul.Maka analisis selanjutkan adalah penelusuran makna yang ada dari teks transformasi novel Sang Nyai.

Rangkaian aksi yang menandai sebuah narasi bukan hanya merupakan suatu rangkaian dalam waktu saja, tetapi juga merupakan rangkaian tindakan yang terdiri dari tahap-tahap penting dalam sebuah struktur.Pada saat pengertian itulah maka muncul persoalan makna yang terkandung dalam rangkaian aksi atau perbuatan tersebut. Dan para pembaca teks dapat melihat pergerakan makna teks dari yang diketahui ke yang tidak diketahui, dan dari yang sederhana ke yang rumit. Ketika bentuknya menjadi novel subjek adalah Samhudi yang bertujuan untuk mendapatkan objek yaitu mencari informasi mengenai sosok Nyai Roro Kidul.

Pada cerita dongeng sosok Nyai Roro Kidul diceritakan sebagai perempuan memiliki kuasa terhadap Senapati cikal bakal Raja Mataram.Ketika cerita ini ditulis dalam bentuk novel popular, subjek cerita adalah Samhudi dan tokoh Nyai Roro Kidul sendiri tidak diceritakan secara eksplisit. Sosok perempuan di dalam novel merupakan tokoh perempuan yang kedudukannnya sebagai tokoh tambahan tidak memiliki peran penting dalam cerita. Tokoh perempuan dalam novel Sang Nyai dijadikan alat oleh laki-laki sebagai alat pemuas hasrat. Di bawah ini akan dibahas lebih jauh mengenai makna peneransformasian yang meliputi objektivasi, demistifikasi dan komodifikasi.

Sosok Nyai Roro Kidul diidentifikasi memiliki kekuasaan terhadap Negara. Berbeda dengan novel, subjek pada novel adalah aku yaitu Samhudi. Alur cerita bergerak berdasarkan pemikiran tokoh aku mengenai hal yang dialaminya sendiri, dan memandang segala sesuatu dari sudut pandangnya sendiri. Sebagai seorang wartawan Samhudi digambarkan memiliki kemampuan untuk melakukan pendekatan secara personal terhadap berbagai individu yang memiliki berbagai macam latar belakang yang berbeda. Banyak akses yang dimiliki seorang wartawan sehingga mendominasi tatanan kehidupan, dengan berbagai hal yang terjadi dalam kehidupan ini. Ketika wartawan seperti Samhudi melakukan pekerjaannya dengan baik maka ia mendapatkan kuasa terhadap berbagai hal yang terjadi sesuai dengan kepentingan tertentu. Dalam hal ini pergerakan cerita ditentukan oleh sudut pandang Samhudi sebagai seorang wartawan yang memiliki kuasa terhadap tokoh-tokoh lain.

Dalam hal ini pandangan subjek terhadap objek yang dilihatnya 
mempengaruhi jalannya cerita. Teks didominasi oleh cara berpikir tokoh aku yang kebetulan dirinya seorang laki-laki memandang tubuh seseorang. Hal ini terlihat dari pandangan Samhudi pada Kesi, pandangan yang menunjukan cara berpikir maskulin, hal itu jelas ketika narator mengatakan kulit pahanya mirip sebuah benda mati yaitu batu pualam.Ketika paha di asosiasikan sebagai batu pualam, besar kemungkinan bahwa narator menggunakan imajinya terhadap sebuah benda yang lekat dengan dunia maskulin.Batu pualam atau dikenal dengan marmer adalah batuan kristalin kasar, yang berwarna putih yang merupakan hasil metamorfosa atau malihan dari batu gamping.Batu merupakan benda keras dan kuat yang lekat dengan nilai maskulin. Samhudi memandang perempuan dalam imajinasinya tidak lebih dari sebuah benda mati mirip batu pualam yang dapat ia imajinasikan sesuka hatinya.

Perempuan juga menjadi objek hasrat pada novel ini, sebagai objek dijadikan alat untuk memuaskan subjek. Hasrat Samhudi sebagai seorang laki-laki muncul pada saat Samhudi melihat lekuk tubuh $\mathrm{Bu}$ Mul, yang pandai merawat diri dengan warna kulitnya yang kuning langsat Sam terkesima padahal $\mathrm{Bu} \mathrm{Mul}$ atau Nyai Mundingsari usianya sudah tidak muda lagi. Sesuatu yang tampak pada peristiwa di atas mengenai kaki dan buah dada merupakan bagian tubuh indah dari seorang perempuan, seolah menjadi daya tarik untuk dibicarakan oleh laki-laki. Lagi-lagi perempuan menjadi objek dari subjektifitas maskulin.
Peran utama dalam novel merupakan tokoh laki-laki hal ini memperkuat dugaan pentingnya peranan tokoh laki-laki dalam Sang Nyai.ketika suara maskulin berbicara dalam hal ini kebetulan suara laki-laki semakin melanggengkan budaya patriarki. Dengan data-data yang ada di atas mengenai bentuk subjektifitas, hasrat dan maskulinitas.Hal ini juga memperkuat dugaan adanya sebuah bentuk kapitalis, kapitalisme disini dipandang sebagai suatu pandangan hidup yang menginginkan keuntungan belaka. Ketika teks ini menampilkan sesuatu yang berhubungan dengan hasrat seksual tentu akan meningkatkan ketertarikan pembaca dewasa sesuai dengan segmentasi pasar yang dituju hal ini dapat menguntungkan pemilik modal untuk dapat meraih keuntungan. Dampak dari pergeseran peran pada teks transformasi, menimbulkan dampak stereotipe gender. Stereotipe gender yang dimaksud sebagai berikut.

Tokoh utama menemui gangguan dan halangan yang memisahkan serta menjauhkan dia dari tujuannya.Dan dia subjek menemui salah paham dalam keyakinannya terhadap sesuatu. Dalam hal ini keyakinan si subjek terhadap mitos Nyai Roro Kidul seperti tampak pada skema aktan yaitu ketika Samhudi sebagai subjek menemui seorang nara sumber yaitu penentang $\mathrm{Ki}$ Aji Sembada yang menentang dan menolak usaha subjek untuk meyakinkan dirinya terhadap kebenaran mitos Nyai Roro Kidul. Karena yang diyakini oleh $\mathrm{Ki}$ Aji Sembada berbanding terbalik dengan keyakinan Samhudi yang sudah 
mengalami kejadian spiritual sebelumnya.

Praktik komodifikasi pada mitos Nyai Roro Kidul ini berarti mengubah, sebagian atau bahkan hampir seluruhnya agar lebih komersial dan memiliki nilai jual tinggi yang tujuan utamanya menarik minat pembaca sesuai dengan kebudayaan popular saat ini. Sebenarnya tidak ada yang salah melakukan komodifikasi terhadap mitos Nyai Roro Kidul, tetapi hal tersebut menjadi salah ketika nilainilai yang ada pada budaya tradisional yang luhur dan sakral menjadi berkurang atau bahkan hilang sama sekali akibat terjadinya komodifikasi terhadap sebuah mitos yang selama ini hidup ditengah masyarakat kolektif pemilik cerita. Hal ini dilakukan semata-mata untuk mendapatkan keuntungan dan menarik minat pembaca untuk membeli novel ini. Selain itu, novel ini akan lebih mudah dipahami sebagai sebuah bentuk kebudayaan masa kini. Lebih dari itu teks transformasi yang berbentuk novel dengan judul Sang Nyaidapat kita interpretasi selain dapat dinikmati dan dibaca oleh semua kalangan pada era modern ini juga merupakan upaya legitimasi mitos Nyai Roro Kidul yang selama ini hidup secara turun-temurun dan dipercaya sebagai mitos yang mempengaruhi pola kesimbangan hidup masyarakat kolektif pemilik cerita agar eksistensinya selalu dapat terjaga. Novel ini pun berusaha mencoba menyampaikan sesuatu bahwa mitos Nyai Roro Kidul dapat menjadi bagian dari kebudayaan modern.

\section{SIMPULAN}

Peristiwa yang menggerakkan alur dalam cerita Sang Nyai terdapat pada skema aktan dasar yang mendasari skema aktan lainnya, yaitu mitos dalam novel dengan subjek Samhudi. Peristiwa pertama, ditandai dengan pencarian informasi mengenai sosok Nyai Roro Kidul. Kedua, peristiwa Mas Darpo kuncen Parangkusumo. Ketiga, peristiwa Kesi seorang perempuan cantik. Keempat, peristiwa Kang Petruk seorang penjaga Merapi. Kelima, peristiwa Nyai Mundingsari seorang janda cantik yang kaya raya. Dan terakhir, peristiwa Nyai Maryatun seorang tokoh batik tulis sido mukti.

Pemanfaatan mitos terjadi pada tataran alur, tokoh, dan latar. Pemanfaatan pada tokoh terjadi karena perbedaan sifat tokoh yang mempengaruhi pada munculnya teknik pelukisan tokoh yang diidentifikasi melalui teknik ekspositori, dan jumlah tokoh. Pemanfaatan pada latar terlihat pada latar sosial dan latar spriritual yang tidak bisa dipisahkan.

Pemanfaatan pada alur menunjukkan pergeseran dari mitos Nyai Roro Kidul yang sakral menjadi tidak sakral.Hal ini menunjukkan adanya pergeseran peran utama dari tokoh perempuan ke tokoh laki-laki, pemanfaatan pada latar menunjukkan perbedaan kedudukan dari sosok Nyai Roro Kidul sebagai penguasa ke rakyat biasa.

Pemanfaatan modifikasi terdapat pada alur, tokoh dan latar. Pemanfaatan modifikasi pada alur dalam novel menunjukkan pola plausabilitas yang dikaitkan dengan realitas kehidupan. Modifikasi pada 
tokoh dilakukan oleh pengarang dengan tidak melepaskan citra masa lalu terhadap mitos Nyai Roro Kidul yang hidup pada kebudayaan Keraton dengan menampilkan tokoh-tokoh yang masih memegang unsur tradisional. Modifikasi latar menunjukkan adanya teknik anakronisme yang merupakan unsur kesengajaan yang dimunculkan pada cerita untuk menjembatani imajinasi antara pembaca dan pencerita dalam novel.

Makna pemanfaatan mitos Nyai Roro Kidul dalam novel Sang Nyai untuk menunjukkan cerita mitos yang tedapat dalam novel merupakan karya baru dan tentunya memiliki makna. Makna pemanfaatan mitos yang dihasilkan dari analisis ini adalah objektivikasi peran Nyai Roro Kidul, demistifikasi, hal ini ditunjukkan dengan adanya anakronisme, plausabilitas, dan komplikasi pada teks yang dapat menghilangkan sifat mistisme pada mitos Nyai Roro Kidul. Makna ketiga adalah, komodifikasi hal ini berkaitan dengan budaya popular, terlihat dari hilangnya nilai sakral pada cerita melainkan sisi komersil yang ditonjolkan pada teks transformasi.

\section{DAFTAR PUSTAKA}

Anwar, Salman Rusydie. 2010. Misteri Nyai Roro Kidul dan Laut Selatan. Jakarta: FlashBooks.

Abdulwahid, Idat, dkk. 1998. Kodifikasi Certa Rakyat Daerah Wisata Pangandaran Jawa Barat. Jakarta: Pusat Pembinaan dan Pengembangan Bahasa Departeman Pendidikan dan Kebudayaan.
Bascom, R. William. 1965. "Four Functiona of Folklore" the Study of Folklore. University af California at Berkeley: Prentice-Hall.

Barthes, Roland. 1987. "Theory Of The Text." Dalam Robert Young (ed.), Untying The Text. A Post Structuralist Reader. London and New York : Routledge and Kegan Paul.

Barthes, Roland. 2007. Membedah Mitos-mitos Budaya Massa. Yogyakarta : Jalasutra.

Culler, Jonathan. 1975. Structuralist Poetics. London: Routledge \& Kegan Paul.

Danandjaja, James. 1994. Folklor Indonesia:Ilmu Gosip, Dongeng, dan Lain-lain. Cet. IV. Jakarta : Pustaka Utama Grafiti.

Daeng, Hans J. 2000. Manusia, kebudayaan dan Lingkungan: Tinjauan Antropologis. Yogyakarta: Pustaka Pelajar.

Damono, Sapardi Djoko. 2005. Alih Wahana. Pusat Bahasa Departemen Pendidikan Nasional. Jakarta.

Dewi, Trisna Kumala Satya. 2009. "Transformasi Mitos Dewi Sri dalam Masyarakat Jawa" (Penelitian). Jakarta: Program S3 UI.

Hall, Stuart. 2011. Budaya Media Bahasa. Yogyakarta : Jalasutra 
Hawkes, Terence. 1977. Structuralism and Semiotics.London: Methuen \& Co.Ltd, h. 87-95

Jauss, H.R 1983, Toward an Aesthetic of Reception Minneapolis ;University of Minnesota Press.

Junus, Umar. 1981. Mitos dan Komunikasi. Jakarta : Sinar Harapan.

Kamus Besar Bahasa Indonesia. 1993. Departemen Pendidikan dan kebudayaan : Balai Pustaka.

Keraf, Gorys. 1986. Argumentasi dan Narasi. Jakarta : PT Gramedia

Ma'mun, Titin Nurhayati. 2010. Teori Greimas Bahan Kuliah MPS di Jurusan Sastra Arab. Bandung : Fakultas Ilmu Budaya

Nurgiyantoro, Burhan. 1998. Transformasi Unsur Pewayangan dalam Fiksi Indonesia. Jogjakarta: Gajah Mada University Press.

Ong, Walter J. 1982. Orality and Literacy: The Technologizing of the Word. London and New York: Methuen.

Pudentia. 1990. "Transformasi Sastra Analisis atas Cerita Lutung Kasarung" (Penelitian). Jakarta: Program Pascasarjana UI.

Pradotokusumo, Partini Sardjono. 1984. Kakawin Gajah Mada. Jakarta : Universitas Indonesia.
Purwadi. 2004. Nyai Roro Kidul dan Legitimasi Politik Jawa.Yogyakarta : Media Abadi.

Riffaterre, Michael. 1978. Semiotics of Poetry. Bloomington: Indiana University Press.

Roger Toll dan Pudentia. 1995. "Tradisi Lisan Nusantara: Oral Traditions from the Indonesian Achipelago a three Directional Approach. Dalam Warta ATL Edisi Perdana. Jakarta: ATL.

Sardjono, Budi. 2011. Sang Nyai: Wajah Cantik sarat Misteri dan Karisma Roro Kidul. Yogyakarta : Diva Press.

Tirtahamidjaja. 2002. Mitos Ratu Kidul dalam Presfektif Budaya.Jakarta : Wedatama Widya Sastra.

Taum, Yoseph Yapi. 2011. Studi Sastra Lisan. Yogyakarta : Lamalera.

Teeuw, A. 1982.Khazanah Sastra Indonesia : Beberapa Masalah Penelitian dan Peenyebarannnya. Jakarta : Balai Pustaka.

Teeuw. A. 1994. Indonesia Antara Kelisanan dan Keberaksaraan. Jakarta : Pustaka Jaya

Tarigan. Guntur Henri. 1985. PrinsipPrinsip Dasar Sastra. Bandung : Angkasa 
Jurnal al-Tsaqafa Volume 13, No. 02, Juli 2016

Vansina, Jan. 1965. Oral Tradition as History. Madison: The University of Wisconsin Press.

Wellek, Rene dan Austin Warren. 1989. Teori Kesusastraan. Terj. Melani Budianta. Jakarta : Gramedia.

Y, Yongky. 2003. Menyingkap Misteri Ratu Laut Selatan Banyu Bening Gelang Kencana. Jakarta : Gramedia.

Z.H, Sudibjo. 1980. Babad Tanah Jawi (Alih Aksara dan Terjemahan Bebas).Jakarta: Departemen Pendidikan dan kebudayaan. 